\title{
The question of access and spatial justice in universities in sub-Saharan Africa: A capabilities approach
}

Author:
Nomanesi Madikizela-
Madiya ${ }^{1}$
Affiliation:
'Department of Educational
Foundations, College of
Education, University of
South Africa, Pretoria,
South Africa
Corresponding author:
Nomanesi Madikizela-Madiya,
madiyn@unisa.ac.za
Dates:
Received: 11 Apr. 2021
Accepted: 12 July 2021
Published: 26 Aug. 2021
mobile device
to read online.
Mow to cite this article:
Madikizela-Madiya, N., 2021,
'The question of access and
spatial justice in universities
in sub-Saharan Africa: A
capabilities approach',
Transformation in Higher
Education 6(0), a124. https://
doi.org/10.4102/the.v6i0.124
Copyright:
@ 2021. The Authors.
Licensee: AOSIS. This work
is licensed under the
Creative Commons
Attribution License.

Background: The discussions related to access in higher education collate enrolment with the provision of education. Yet, when considering what the university education should provide, some enrolments still restrict capabilities, freedom and rights to quality education. The article argues that the debates regarding access to higher education are incomplete without addressing this divide.

Aim: The article aims to expose the injustices that exist in some university spaces in sub-Saharan Africa. Space is politically and ideologically produced, a situation that legitimises a need for the exposure of injustices in terms of access to quality and dignified physical and technological resources for education. The article posits that if the spatial injustices that are embedded in the universities are not exposed, the universities will fight endless battles towards providing adequate access for students and academics.

Setting: The article reports on research conducted in three of the seven universities in sub-Saharan Africa that participated in a research project.

Method: A multiple qualitative case study design was followed. Data were generated through semi-structured interviews with academics and focus group interviews with students in the universities.

Results: Quantity and quality of the physical and technological structures in these universities are dehumanising, unjust and unfair to students and staff who must compete economically with their counterparts in other spheres of society.

Conclusion: The physical and technological structures in the universities demand a reconceptualisation of access. Presently, transformation, as it pertains to access and spatial justice, is minimal. A focussed developmental strategy is proposed for the universities in order to improve and provide relevant access to knowledge and skills for relevance and quality.

Keywords: Higher education access; spatial justice; capabilities approach; spatial conditions; higher education inequalities; rights and freedoms; sub-Sahan Africa; technological development.

\section{Introduction}

Access to higher education is a more complex topic than is often portrayed. This is because it is one thing to have access to the university from outside and it is another to access quality education in a spatially just context when already in the university. There has been copious research on issues related to the former, but not much on the latter. For example, researchers, such as Martinez-Vargas, Walker and Mkwananzi (2020), Mathebula (2019) and Alger (2018), map the various contextual factors that limit access to higher education of students from disadvantaged backgrounds and their success in this area. Some such researches critique the under-preparedness of students at school level to transition smoothly to university (Mendaglio 2013; Nel, Troskie-de Bruin \& Bitzer 2009; Walker 2019; Wilson-Strydom 2015, 2016). There are also some researches on the issues related to epistemological access in terms of legitimated knowledge at university level (Ellery 2017; Ruszynyak et al. 2017) or to diversity and statistics of access (Alger 2018).

However, not much attention is paid to access in, rather than to, higher education in terms of capabilities, justice, democracy and inclusivity. Yet, in the contemporary higher education context, where students have preferences regarding the spaces of learning and teaching (Beckers, Van der Voordt \& Dewulf 2016; Zeivots \& Schuck 2018), institutional spaces may be 
both intentionally and unintentionally inadequate for access to quality education. It is also interesting to note that there is only limited research on university staff's experiences of institutional spaces (Madikizela-Madiya 2016) whilst they should be facilitating and supporting the enrolled students in adequate spaces to access quality education. Therefore, in this article, I argue that if research conceptualises access as meaning only enrolment, the injustices that constrain other aspects of access will not be exposed. This is a problem because students in all universities aspire to be competitive in their areas of socio-economic practice once they complete their studies. However, some spatial conditions may exclude them from accessing the required quality education. Such exclusion may, in turn, disadvantage them when socioeconomically competing with those who received quality education for employment. As Sen (2000) argued:

$[B]$ eing excluded from the opportunity to be employed or to receive credit may lead to economic impoverishment that may, in turn, lead to other deprivations (such as undernourishment or homelessness). (p. 5)

Thus, the exclusion from access to quality education may reproduce the very reasons that might have landed them in the less empowering universities - constrained freedom to choose universities.

I use the capabilities approach (CA) to analyse how spatial conditions in some universities in sub-Saharan Africa constrain access to quality teaching and learning. Spatial conditions in this case refer to the university resources in terms of buildings and teaching and learning materials, as well as to safety and wellness in the universities. The CA is a framework that helps in the analysis of "what people are effectively able to do and to be, that is, [what] their capabilities [are]' (Robeyns 2003:5; see also Nussbaum 1997, 2011; Sen 2000, 2005; Zheng \& Walsham 2008). Amongst its key concepts are freedom, functionings and capabilities (Hatakka \& De' 2011; Robeyns 2003; Sen 2005; Zheng \& Walsham 2008). I use this framework together with the concept of spatial (in)justice (Moroni 2020; Soja 1989). The concept of spatial justice resonates with the $\mathrm{CA}$ as it denotes 'desirable spatial situations and arrangements occurring within a certain just institutional framework' (Moroni 2020:255; Van Wyk 2015). An opposite of this situation is injustice: it limits the capabilities to do what students enrol in a university for, what they wish to be in society and what academics can do to facilitate learning.

The article begins with a review of literature on access to higher education in order to elaborate on the issues that are predominant in such literature and to highlight the reasons why access is more than just admission and enrolment. The second section presents the conceptual framework, starting with the CA and continuing to spatial justice. These concepts assist in the analysis and interpretation of data. The third section focusses on the methodology that was followed to develop data. The research findings are presented in the fourth section, followed by the discussion of findings in the fifth section and conclusions in the sixth section.

\section{Access to higher education conceptualised}

As indicated, the dominant literature on access to higher education collates two concepts: enrolment and provision of education. This situation is identifiable from the factors that are mentioned as constraining access to higher education. For example, Lusigi (2019:9) found that disparities of access in sub-Saharan Africa were based mainly on gender: 'In at least [eight] countries included in the sample of 25 countries, the share of women enrolled in tertiary education is higher than for males'. This resonates with McCowan's (2012:113) argument that 'no one should be barred from [access to] higher education for any reason other than "merit," i.e. not through financial disadvantage etc.'. Both these statements do not include the internal institutional conditions, but refer to enrolment as access.

In South Africa, besides enrolment, access to higher education is conceptualised as a requirement for transformation following the history of apartheid that restricted enrolment in universities based on race, after which affordability became an issue for those from disadvantaged backgrounds (MartinezVargas et al. 2020:428). In this case, access is about inclusion in consideration of identity and advantage. Similarly, Dlamini (2018:61) extended the political implications of access to the wider southern Africa in terms of curricula and knowledge that are delivered and accessed in universities. Dlamini (2018:61) argued, 'It is high time we unchain ourselves from the Western-Euro-controlled education and create education systems that are responsive to the needs of the continent'. Dlamini made this comment in response to Kallaway's (1984) argument that the Southern African cultures and ideologies were transformed through the colonial education system. Because of this history, African higher education has been hampered by the need to transform curricula and equity.

Whilst all the issues about access that are discussed in the above-mentioned literature are equally important for the transformation of higher education in terms of enrolment as access, scant attention has been given to the question of what that access should be for and whether the spaces enable the attainment of that reason. The identification of what the university should provide is a key to demarcating enrolment and provision of quality as two aspects of access to higher education.

There are expectations regarding the spatial conditions and practices that define university education. Duderstadt (2000), for example, observed the value of university education in the knowledge age, where knowledge has become the wealth of the nations: 
[T] he educational opportunities offered by the university, the knowledge it creates and the services it provides are key to almost every priority of contemporary society, from personal prosperity and well-being to economic competitiveness to national security to protecting the environment to enriching our culture. (p. 4)

On a similar note, Barnett (1988) identified the following as some of the key notions of the university:

$[T]$ he advancement of knowledge and the initiation of others into it; the development of knowledge that can be applied to the practical needs of the community; and the provision of opportunities for liberal education, in the sense of all-round understanding. (p. 243)

Therefore, enrolment to university is purposefully sought for advanced knowledge. Restrained access to such knowledge, whether in terms of entrance to the university or full capability to participate and learn when inside, is injustice. In this regard, Lusigi (2019:2) argued that ' $h]$ igher education is expected to advance economic growth through its contribution to human capital development, fostering innovation and technology transfer'. Speaking of sub-Sahara Africa, Fonn et al. (2018) noted, 'Universities [are] expected to train the professionals needed in the expanding public service, to extend the frontiers of knowledge, and to serve the national economy'. On the same note, Lusigi (2019:3) argued, 'For higher education to play a role in Africa's transformation it must be transformational [...], fit for purpose [and enable] people to live meaningful lives $[\ldots]^{\prime}$. All this requires adequate and just learning spaces so that individuals and communities attain development. As Mukwambo (2016:51) asserted, human development is 'inextricably' linked to quality higher education: it is 'related to human development through its process of expanding the choices people have' (Mukwambo 2016:56). This author further noted the instrumental and intrinsic value of education as it provides:

[I]mproved access to better career opportunities, earnings and life prospects and [...] increases the possibility of appreciating and engaging in a wide range of activities that are fulfilling for their own sake; for example, the enjoyment of art, critical thinking and civic participation. (Mukwambo 2016:57)

All this, according to Mukwambo (2016), is made possible by the existence of favourable conditions. Therefore, it should be understood that access to higher education includes capabilities to attain relevant education for self and community development, as suggested in this literature. This matter is highlighted by Walker and Mkwananzi (2015) who argued that:

$[W]$ hile higher education budget figures and statistics are helpful in painting the broad picture of higher education access numbers, these cannot tell us much about actual lives or alert us to who is left out and why, and what individual advantage is possible for each person. (p. 41)

This is a problem because higher education should be about capabilities, as explained in the next section.

\section{The capabilities approach and access to higher education}

The CA, (also known as the human development approach) (Nussbaum 2007), is a framework mainly associated with Amartya Sen who proposed it in regard of 'development as the expansion of people's freedoms' (Hatakka \& De' 2011:1). This framework was initially developed for discussions on economics but has since been used across disciplines, focussing on capabilities such as 'access to healthcare, education, participating in economic life and the autonomy in decision making' (Zheng \& Walsham 2008:224). Sen (2004) also noted that this approach can be used for a wide range of assessments and evaluations in pursuit of just societies.

According to Zheng and Walsham (2008:224) as well as Wilson-Strydom (2011), the concern of the CA is whether people have opportunities to lead lives that they can value. This approach has key concepts that guide the analysis or evaluation, such as 'opportunities, functionings, capabilities, choices, values, quality of life, alternatives and freedom of individuals in understanding social justice' (Ndofirepi 2020:396). In the context of education, the CA is concerned with achieving the 'beings and doings' that individuals 'have reason to value, that is their well-being, offering a justicebased lens for education in which real lives and social structures are taken into account' (Proctor \& Anand 2017; Walker \& Mkhwananzi 2015:41). To clarify the concept of functionings, Basu and López-Calva (2011) added 'goods' as another component of capabilities and provided an example:

$[A]$ functioning is what a person manages to do or to be. A good can enable a functioning but is distinct from it. A bicycle is an item, whereas being able to transport oneself rapidly to work (or, more importantly to most people, away from work) is a functioning. (p. 154)

Basu and López-Calva further indicate that there should be a consideration as to whether the person had 'an opportunity, freedom and advantage' to function. For example, did the person have the means to do something and chose not to, or was the person denied doing it in anyway? Ndofirepi (2020:398) used this approach to explore 'how students negotiate social spaces on campus, and what their experiences are that enhance or constrain their functionings and capabilities'. Capability in Ndofirepi (2020)'s study referred to 'what the students gain - what they are able to do considering their personal and social situations or their actual opportunities to do and be what they have reason to value on campus spaces' (p. 398). Tumuheki, Zeelen and Openjuru (2016) also used the CA to frame their research in Uganda regarding the participation of 'non-traditional students' in Makerere University and they found internal and external hinderances constraining such participation. Thus, the framework is relevant for higher education research and for this article because it guides the identification of functionings, goods, choices and other concepts in relation to spatial justice in the institutions concerned. 


\section{Conceptualising space}

There is growing interest in research on space and higher education practices (Kuntz, Petrovic \& Ginocchio 2012; Ndofirepi 2020; Temple 2009). However, as Middleton (2018:6) argued, '[s]pace is a problematic term, hard to nail down and having many meanings $[\ldots]^{\prime}$. This article is about institutional space which, according to Ellis and Goodyear (2016:149), is conceptualised in two ways: an abstract space that requires quantitative measurements, and a qualitative space of people's experiences. According to the first view, it is 'space that can be managed at a high level, using financial and other quantitative measures, and using categories that necessarily strip away many of the detailed features of individual places'. Therefore, the required research in this case would quantitatively count 'observable behaviours and [calculate] variations in space usage' (see also Chattaraj \& Vijayaraghavan 2021). In the second view, researchers identify qualities of learning spaces according to how they produce success, fulfilment and relevance in terms of outcomes. In this article, I adopt the latter view with an understanding that institutional spaces, whether physical or virtual, have an important bearing in enabling or constraining teaching and learning and student support. As Luz (2008:1) posited, space has 'the ability to define how one learns, teaches, acts or responds'. As such, space is 'a complex interweaving of physical, virtual, social, cognitive, and emotional' dimensions (Chattaraj \& Vijayaraghavan 2020:4) which should all work together for quality teaching and learning. Therefore, research that connects pedagogy and space is necessary. In this regard, Ellis and Goodyear (2016) argued that connections between space and learning:

[... Can] be subtle and powerful. To understand them, one needs to understand complex, shifting assemblages involving human beings and things: material, digital and hybrid. Research aligning with this view tends to the qualitative: exploring students' and teachers' experiences and foregrounding subjective meanings and sense-making. (p. 150)

Thus, space is not just a container in which academic practices take place.

\section{Spatial justice in higher education}

Students and staff can function better if the spaces in which they work are just; if the spaces subscribe to social justice in terms of dignity and fairness (Dikeç 2009). Just spaces in higher education enable freedom, capabilities and a wide range of choices for social justice (Nussbaum 1997, 2011; Sen 2000, 2005; Zheng \& Walsham 2008). Such spaces provide education that enables:

$[P]$ eople to grow, to be informed, to be articulate, to care about others, and through this process, to lead pluralistic flourishing lives and contribute to the flourishing lives of others [...]. (Walker \& Wilson-Strydom 2017:9)

Advocating for the adequacy of both the digital and the physical learning space, Middleton (2018) argued: $\left[\begin{array}{ll}\ldots & I\end{array}\right] \mathrm{t}$ is evidently not enough to organise learning around simple dominant notions of space when the aim of higher education is to develop knowledgeable, critical, creative, resilient and agile people [...]. Students need to develop capabilities that will make them confident and agile in the world that is unpredictable and that demands critical and creative engagement. (pp. 8,9)

To this end, Ndofirepi (2020) indicated that a question should be whether students (and staff) have freedom to choose and whether they have affordances to utilise the spaces - therefore, whether the spaces are just. Thus, spatial justice is a judgement subjectively given, based on experiences of situations concerned. As Pirie (1983:467) posited, '[T] he justness of a situation may be decided by the person whom it directly affects'. Regarding this issue, Wilson-Strydom (2014) argued:

$[W]$ hen we consider issues of justice or injustice, we cannot merely ask whether different people have achieved the same outcome, but rather, whether different people have had the same opportunity to achieve this outcome. (p. 151)

This statement relates to capabilities, choices and functionings. To understand the concept of spatial justice better, one would have to look at its opposite: spatial injustice. Dikeç (2009:1793) described spatial injustice as 'a critique of systematic exclusion, domination, and oppression; a critique aimed at cultivating new sensibilities that would animate actions towards injustice embedded in space and spatial dynamics'. These issues could be overlooked if space is taken for granted.

One of the obvious injustices in higher education in South Africa is the inequality regarding technological, physical, human or intellectual resources. Like other spaces, institutions are organised into 'dominant centres and subordinate peripheries' (Soja 1980:209). Some institutions are metaphorically at the centre whilst others are at the periphery regarding the required resources for practice and learning. These inequalities are not coincidental but are a product of the past and the present ideologies and practices (at a macro-level). How the resources in the institutions (at a micro-level) serve the institutional actors (e.g. students, managers, administrators) depends on ideologies, relations and interactions; these constitute the institutional space. In other words, injustice in universities is the limiting actions or non-actions of the powerful structures and individuals who can make changes. Such individuals and structures can be at either government or institutional level. Moroni (2020) used an example of 'the just city' to speak about institutional justice:

[I]f we speak, for example, of the injustice of certain urban situations - for example, the state of certain peripheral neighbourhoods or the inaccessibility of certain basic urban services - we are actually assuming implicitly that what is unjust in reality are the urban institutions that have allowed such situations to arise and do not intervene in order to correct them. (p. 254)

But apart from the issue of inequality in terms of resources, injustice can also be viewed in terms of security, health safety and protection against violence and hazards in the 
institutions. These are aspects of social justice, according to Drysdale, Modzeleski and Simons (2010) and Sulkowski and Lazarus (2017). In terms of health, Ruger (2004:1076) argued that it affects human functionings, 'including agency, the ability to lead a life one has reason to value'. Therefore, spaces that suppress health, deny freedom and capability to be and to do. Johnson et al. (2011:149) were of the same view, arguing that health provides the capability to 'participate fully in the workforce [whilst] ill health means potential suffering, disability and/or loss of life, [and] threatens one's ability to earn a living $[\ldots]^{\prime}$. Therefore, there is more to spatial justice than just the resources, but the first step is to identify the injustice, as the research on which this article is based aimed to do.

\section{Methodology}

The article draws from a collaborative research project in which seven institutions in sub-Saharan Africa participated: five South African, one Ugandan and one Zambian. For reasons of confidentiality, the names and types of the institutions are not disclosed (Surmiak 2018, 2019). The main question of the project was how university spaces enabled or constrained spatial practices such as teaching and learning, research, administration and management. The article deliberately focusses on the constraints without implying that the participating institutions do not have any positive aspects. The intention is to share knowledge for possible alterations to the constraints.

A qualitative multiple case study design was followed (Gustafsson 2017) in order to identify contextual spatial conditions and to compare data. In total, there were 19 collaborators (seven at the host institution and two at each of the other six). Collaborators used the ethical clearance from the host institution to request permission to conduct research from their institutions (Morris 2015). Data were collected through policy analyses, participant observations and face-to-face semi-structured interviews with academics, administrators and managers at varying levels in the education faculties. One focus group interview per institution was conducted with students who also participated in a survey in each institution. The number of participants in the surveys varied because of different enrolment and response rates in the various institutions. However, the invitation was sent to all students in the education faculties who were in their third year of study. The researchers chose this cohort with the assumption that the students would have been in the institutions long enough to provide in-depth information about the spatial conditions. Each focus group was comprised of eight students who served in the student representative council. The survey data are not included in this article as it did not form part of the information that is being shared. The survey provided mainly the demographics and quantitative data that were not especially informative for this particular article.

Following purposive sampling (Sharma 2017), 10 academics per institution in the faculties of education were interviewed. The criteria were that these academics should be teaching the students' group in the survey, that is, the third-year students, and they should also have been in the institutions for at least 3 years so that they would have a fair understanding of changes or lack of changes in the institutional spatial conditions. To maintain anonymity and confidentiality in this article, the universities are referred to as 1,2 and 3. Academics are coded (e.g. A1-1 for Academic 1, University 1; A3-1 for Academic 3, University 1). Students are coded (e.g. S1-1 for Student 1, University 1; S1-3 for Student 1, University 3).

Data were analysed thematically (Vaismoradi et al. 2016). Project members held seminars to discuss the data and each sub-team drew themes from the data subsets. The limitations were that the project had more data from the host institution where there were more researchers than in the other institutions. However, all data were made available to all the researchers. This article reports on data drawn from three of the universities. These were the universities that had similar spatial conditions in terms of constraints. Most students in these universities were from less advantaged backgrounds. The article reports on only the interviews with academics and students, from which data the themes related to spatial injustice emanated.

\section{Research findings}

In an effort to understand how spatial conditions in some universities in sub-Saharan Africa constrain access to education, I analysed the interviews conducted with students and academics, guided by the CA and the concept of spatial justice. Although 10 academics and eight students per institution were interviewed, the findings presented in this article are selective towards addressing the question for this article. Thus, not all the voices of the participants are identifiable but only those that spoke to the question.

The first question I asked myself as I engaged with the data was: How do the spatial conditions affect the functionings related to teaching and learning for quality education? How do such conditions relate to justice?

The theme that related to this question was each university's carrying capacity. For the sake of dignity and adequate access to quality education, both students and staff at universities deserve sufficient and well-resourced spaces. This is hardly the case in the three universities because their populations have been growing over the years, but the resource provision has not been exponential. As a result, ' $t$ teaching venues are much smaller than the required for the registered number of students' (A1-2).

To attend to this situation of increased student and staff populations, the universities have had to find alternative spaces for teaching. A1-3 commented:

'Due to the increase in student numbers, other venues like the auditorium and a dining hall are used for lecturing purposes. These venues were not [designed] for teaching - lecturers have difficulty in projecting their voices and as a result, students make noise and some of them do not concentrate.' (Academic participant 3 in University 3) 
A similar situation was also found in Universities 1 and 2 . In University 1, they, sometimes, use the chapel with similar conditions as the dining hall. With reference to University 2, A2-2 stated that she would teach more than 500 students in a former dining hall where there was no support material at all (such as projectors, microphones or other voice-projecting tools). She needed to project her voice higher than the usual pitch in an attempt to be audible to the students at all sides of the hall. She commented, 'My left ear is affected. It is often painful, and I think it is because of this situation'.

Therefore, the inadequacy of lecture theatres in University 2 - which is an injustice in terms of resources - builds up to a life-threatening injustice to this participant. The possibility in this case is that the lecturer could fall seriously ill and the students would miss out from being taught because the technological resources that could be utilised in the teacher's absence are either insufficient or not available. Therefore, the lecturer's incapability to function in a just manner because of the spatial conditions would translate to an incapability for students to learn.

The next question was: What can students not do because of spatial conditions?

The overpopulated lecture theatres are uncomfortable to students in more ways than one. Students in University 3 commented:

'They allocate one hundred students in a lecture hall that can accommodate only fifty [...]. It becomes the survival of the fittest when it comes to class attendance. If you were held up in another class, you must stand for the whole hour and you cannot learn successfully.' (Student participant 4 in University 3)

Quality is challenged in two ways here. Firstly, the student's focus in the first classroom could be impeded by the thought of having to run and compete for comfort in the next room. Secondly, in the next room, the student is unable to learn best whilst standing.

Another student concurred:

'Yeah, even if it's hot - because it will be hot in class - you will be sweating and standing, which becomes a very big problem.' (Student participant 1 in University 3)

This situation suggests that the unjust conditions are detrimental not only to the lecturers and students' health, but also to their learning and possibilities for success. Thus, access to quality is challenged.

Apart from capacity, there were also issues regarding the designs of teaching and learning spaces. I asked myself, how do the structural designs affect functionings, freedom and capabilities in the universities?

The findings indicated that in two of the three universities, the designs of lecture theatres were described as unsupportive and therefore not inclusive in terms of different (dis)abilities of the university population: 'Most of the classrooms were built in an old fashion theatre configuration, with a lot of steps and fixed furniture' (A2-2). Such designs also 'restrict active interaction and engagement and prevent students from doing group work and collaborating with each other' (A2-2).

\section{Similarly, A1-3 commented that:}

'[T]here is no interaction, there is no movement, you can't move the chairs - it's like you are preaching to your students. I think that is a very traditional [positivistic] setup.' (Academic participant 3 in University 3)

In which the lecturer knows all and should instruct the students.

This is a clear restriction on capabilities in these institutions because the academics know what they want to do in the lecture theatres and how to do it, but the conditions inhibit their freedom. The students in the same universities also raised the concern of not being able to do group work freely when in class. Thus, if learning can occur through knowledge sharing amongst students during lectures, then in these particular universities, such learning is restricted.

\section{How does spatial planning infringe on freedom to teach and to learn?}

Apart from the unfriendly theatres, challenged planning of the timetables because of insufficient spaces seemed to pose possibilities for conflict in the universities. In University 1, A1-1 noted:

'[T] here are clashes in the timetable, whereby you will go to a class and you get other people there and then you must move up and down. There is no control of who is supposed to be here and who is not supposed to be there.' (Academic participant 1 in University 1)

Situations like these would be regarded as ridiculous in the institutions where spaces are sufficient and well planned in terms of time tabling, but they are a reality in these universities.

Even in terms of the teaching support tools, A3-2 commented that 'not everyone has access to the available projectors as they are available on a first come first serve game'. Thus, it was evident that it was not enough to analyse the conditions of the teaching and learning theatres without also looking at the tools for the facilitation of access to quality education.

\section{How does limited access to technology infringe on the rights and freedom to access quality education?}

Access to technology for quality teaching and learning is a spatial justice issue because whilst the global higher education sector is discussing how to enhance the tools that have always been in use, these sub-Saharan universities are still deliberating how to source them. There is a dire 
shortage of technological resources in the universities. Referring to the available computer laboratories, S1-3 commented:

' $[T]$ hese computer labs are lecture theatres for computer science students. There are hundred computers but at any time, fifty or fewer of them are working.' (Student participant 1 in University 3)

\section{A similar experience in University 1 was shared by (S1-1):}

'[I]t becomes very difficult for computer students in our faculty because there are about more than a thousand of them doing the module but when they go there, only a limited number of computers are working.' (Student participant 1 in University 1)

This situation suggests that the university in question is trying to provide the teaching tools, but maintenance appears to be the challenge; thus it affects quality teaching and learning and therefore access to quality education in particular courses.

\section{Apart from specific courses, how is the freedom to access knowledge restricted by the shortage of computers?}

In University 1, there were no computer laboratories that were not used as lecture theatres. S6-3 added that the laboratories were occupied by different groups of computer science students the whole day and they closed at designated times. Therefore, they were not fully accessible to the entire student population. Even when the students happened to access the computers, they were restricted in terms of what they could do: 'We are not allowed to access YouTube videos to watch online lectures. I think that one needs to be addressed' (S2-2).

\section{How do the spatial conditions suggest inequalities in higher education?}

Participants were aware that their counterparts in other universities did not have similar experiences. For example, A2-3 commented:

' $[I]$ would like to see a situation where, like in some universities, every student will have a digital device that can have internet access via $\mathrm{Wi}-\mathrm{Fi}$ and that can have a system where if you ask them questions that they can type immediately, the answer appears on the board and we can have a discussion from that.' (Academic participant 2 in University 3)

In the same institution, S7-3 commented that she felt ashamed when she did not know much about computer functions because she had limited access, so she was not able to learn from them:

'I am in the third year of study, but my friend who goes to [University Z] came back telling me so much about information in the computers. I am in year three and he is in year one. What is that? I felt so ashamed!' (Student participant 7 in University 3)

This response suggests that the student was comparing himself to the friend and was, therefore, aware that there are better functionings and capabilities that the friend received from the other institution. The statement that he was ashamed suggests that he might struggle to compete in the socio-economic environment with the other students.

\section{How do the spatial conditions steal the freedom of staff to utilise their personal resources?}

The shortage of resources in University 1 led to a point where academics sacrificed their research funds, which they could decide to use as they wished, to purchase teaching resources. For example, A2-1 stated:

' $[I] \mathrm{t}$ is hard to establish the exact number of computers in this University because over $60 \%$ personally belong to staff. They are project ICT facilities secured by staff in their respective projects.' (Academic participant 2 in University 1)

A clear spatiality of this problem concerning accessibility of technology could be drawn from this comment by A3-1:

' $[W]$ hilst we try as academic staff to source funds to purchase the technological tools and the university assists by servicing them, we are let down by the systematic erratic nature of internet connectivity, especially in the course of the day when most needed for teaching and learning.' (Academic participant 3 in University 1)

It appears that the above-mentioned problem was because of the geography of this university because in the contexts where teaching and learning are wholly based on technologies, the same problems about connectivity cannot be the order of the day.

\section{How do the libraries contribute to the spatial injustices?}

University education is primarily about reading and writing. Therefore, limited access to the library resources is an injustice of the highest order. Such injustice was also identified in the participating institutions. There was limited space for students in the library because of the expanding student population. In addition, S4-1 raised another issue, namely that 'most library books are outdated. You will think there is information there, but it is not there because the library is full of old books'. S2-1 added: 'You can also find that a book has [only] one copy'.

Besides limited capacity and outdated or insufficient books, University 2 students mentioned that the library had no computers for use by students. For example, (S1-2) commented:

'[Y]ou can only search for books in the library. If you want to search E-books you have to go online during your own time. But you can't access that in the library.' (Student participant 1 in University 2)

Therefore, in these universities, the main sources of information for students - the library and technology - were insufficient. A situation where a student cannot afford to buy his or her own computer, and the library has either outdated books or only one copy per book is untenable. 


\section{Discussion of findings}

The concern that this article intended to address is the tendency of higher education literature to collate enrolment and the provision of education when discussing access (Lusigi 2019; McCowan 2012), thereby paying less attention to the role of institutional spaces in enabling or constraining capabilities, freedom and rights to access quality education. The article showed that in the institutions concerned, it is not only a matter of students and staff preferences of learning and teaching spaces (Beckers et al. 2016; Zeivots \& Schuck 2018), but also there are injustices ranging from inadequacy of physical and technological resources to even healththreatening ones (Johnson et al. 2011; Ruger 2004). The situation where a lecturer suffers from ear pain indicates how the space in the university creates incapability to function safely for the benefit of self (through teaching as an academic identity development trajectory) and students in a just space.

Students in these universities are excluded from the freedom to source knowledge from computers, the library, free and comfortable interaction with the lecturers as well as with each other. This situation can possibly exclude them from economic freedom in a competition-prone society (Sen 2000). Thus, both the teachers and staff are unable to teach and learn as they would wish to (Nussbaum 1997, 2011; Robeyns 2003; Sen 2000, 2005; Zheng \& Walsham 2008). The academics' freedom to use their research funds as they wish is curtailed by the sacrifice they make in buying computers to limit the injustices that impede the quality of learning for students.

It is clear from the research reported in this article that whilst enrolment intended to provide access for transformation in higher education (Dlamini 2018; Martinez-Vargas et al. 2020), students and staff at the universities in this study are aware that there are better conditions in other universities. This makes them feel uncomfortable in the places where they are, making these places undesirable and therefore unjust (Moroni 2020:255; Van Wyk 2015). Justice in higher education is equivalent to the ability to access education that prepares one for 'personal prosperity and well-being [for] economic competitiveness' (Duderstadt 2000:4). Yet, students in the universities in this study do not have full access to the basic spatial requirements, as they very often have to stand throughout a lecture, and in many instances, they are unable to interact with each other because of the design of the spaces.

Mukwambo (2016:51) asserted that human development is 'inextricably' linked to quality higher education. It can, therefore, be said that development for students in these institutions is distorted because their education is not of quality. Their functionings, capabilities and 'quality of life' (Ndofirepi 2020) are unjustly constrained.

\section{Conclusion}

This article used the CA and the spatial justice concept to address the question of how spatial conditions in some universities in sub-Saharan Africa restrict access to quality education when students are enrolled. The findings revealed spatial injustices pertaining to various forms of resources and how such injustices affect access to knowledge and dignified practices. There are injustices in these universities because of limited freedom, capabilities, choices and goods (Nussbaum 1997, 2011; Sen 2000, 2005; Zheng \& Walsham 2008). Students and staff in these universities have limited opportunities to grow academically because of the unjust spatial conditions. The findings also illustrate how sub-standard education for the disadvantaged communities has been naturalised in these universities through spatial designs and plans as well as spatial practices - some of which sound unbelievable but are real to those who experience them, those who are directly affected by their unjust nature (Pirie 1983).

Whilst the world speaks of digitisation and automation of knowledge and practice in higher education, there are still disquieting socio-spatial injustices that haunt some universities in sub-Saharan Africa and which, if justice matters, should not be overlooked. Two main conclusions can be drawn from the above-mentioned findings. Firstly, the universities concerned are still struggling in terms of technological development and the development of their physical infrastructure. Consequently, they are unable to provide and maintain decent spaces for access to quality knowledge and skills. Students are exposed to outdated information and limited access to technology. Because these universities are in a world where technology is taking over, they may be advised to focus on one of the problematic spaces - technology. If technology is sufficient and adequate, the institutions would need to focus on maintaining their quality without also worrying about the buildings. Secondly, students in the universities concerned do not receive adequate knowledge and skills to be able to compete in society. This situation reproduces inequality and may perpetuate low self-confidence in both students and lecturers. This state of affairs can also be addressed through the provision of up-to-date technological resources so that students will not be unfairly restricted to source knowledge. Considering that the world has rapidly become technology vested, it might be advantageous if the universities concerned were to put more effort into developing technology to limit or do away with the need for physical theatres. If that were to happen, students would have access to current information rather than the outdated books in their physical libraries. It is not enough to be in the university. It is unjust to have sub-standard resources whilst one is expected to go out and compete economically with one's counterparts that have received quality education, in quality spaces and with quality resources.

The research has shown that exploring higher spaces qualitatively (Ellis \& Goodyear 2016) can provide information that can possibly be used if governments in the countries concerned can access it. Therefore, further research on how such findings can be transformed into practical knowledge 
for higher education development in sub-Saharan Africa can be of value. Also, empirical research to compare the data presented here with institutions that are regarded as advantaged and well-resourced can provide an important knowledge for attending to inequalities in higher education and to reduce the systematic exclusions to access and justice.

\section{Acknowledgements}

A word of appreciation is sent to all the institutions that participated in the project 'The dynamics of higher education space and place in Sub-Saharan Africa'.

\section{Competing interests}

The author declares that no financial or personal relationship(s) have inappropriately influenced the writing of this article.

\section{Author's contributions}

This article is solely authored by Dr Nomanesi MadikizelaMadiya.

\section{Ethical considerations}

The CEDU Research Ethics Committee of the College of Education, University of South Africa approved the study. 2016/10/19/90174267/26/MC.

\section{Funding information}

The project from which the article draws was funded by the National Research Foundation (NRF).

\section{Data availability}

The data that support the findings of this study are available on request from the author, NM. The data are not publicly available because they contain information that could compromise the privacy of research participants.

\section{Disclaimer}

The views and opinions expressed in this article are those of the author and do not necessarily reflect the official policy or position of the author's institution or the funders.

\section{References}

Alger, J.R., 2018, 'Access to success - Making campuses both diverse and inclusive' in S. Bergan \& I. Harkavy (eds.), Higher education for diversity, social inclusion and community: A democratic imperative, pp. 63-73, Council of Europe Publishing, Paris.

Barnett, R.,1988, 'Does higher education have aims?', Journal of Philosophy of Education 22(2), 239-250. https://doi.org/10.1111/j.1467-9752.1988. tb00197.x

Basu, K. \& López-Calva, L.F., 2011, 'Functionings and capabilities', in K.J. Arrow, A. Sen \& K. Suzumura (eds.), Handbook of social choice and welfare, pp. 154-183, Elsevier

Beckers, R., Van der Voordt, T. \& Dewulf, G., 2016, 'Learning space preferences of higher education students', Building and Environment 104, 243-252. https://doi. org/10.1016/j.buildenv.2016.05.013

Chattaraj, D. \& Vijayaraghavan, A.P., 2021, 'Why learning space matters: A script approach to the phenomena of learning in the emergency remote learning scenario', Journal of Computers in Education. https://doi.org/10.1007/s40692021-00182-z
Dikeç, M., 2009, 'Space, politics and (in)justice', Spatial Justice 1, viewed 19 January 2021, from http://www.jssj.org/article/lespace-le-politique-et-linjustice/.

Dlamini, R., 2018, 'Corporatisation of universities deepens inequalities by ignoring social injustices and restricting access to higher education', South African Journa of Higher Education 32(5), 54-65. https://doi.org/10.20853/32-5-2162

Drysdale, D., Modzeleski, W. \& Simons, A., 2010, Campus attacks: Targeted violence affecting institutions of higher education, viewed from https://books.google. co.za/books?

Duderstadt, J.J., 2000, A university for the 21st century, Michigan, The University of Michigan Press, Ann Arbor, MI.

Ellery, K., 2017, 'A code theory perspective on science access: Clashes and conflicts', South African Journal of Higher Education 31(3), 82-98. https://doi. org/10.20853/31-3-1306

Ellis, R.A. \& Goodyear, P., 2016, 'Models of learning space: Integrating research on space, place and learning in higher education', Review of Education 4(2), 149-191. https://doi.org/10.1002/rev3.3056

Fonn, S., Ayiro, L.P., Cotton, P., Habbib, A., Mbithi, P.M.F., Mtenje, A. et al., 2018 'Repositioning Africa in global knowledge production', The Lancet 392(10153), 1163-1166. https://doi.org/10.1016/S0140-6736(18)31068-7

Gustafsson, J., 2017, Single case studies vs. multiple case studies: A comparative study, Academy of Business, Engineering and Science, Halmstad University, Halmstad.

Hatakka, M. \& De', R., 2011, 'Development, capabilities and technology - An evaluative framework', paper presented at the 11th International Conference on Social Implications of Computers in Developing Countries, Kathmandu, 22-25 May, 2011.

Kallaway, P., 1984, Apartheid and education, Johannesburg, Ravan.

Kuntz, M.A., Petrovic, J.E. \& Ginocchio L., 2012, 'A changing sense of place: A case study of academic culture and the built environment', Higher Education Policy, 25 433-451. https://doi.org/10.1057/hep.2011.29

Lusigi, A., 2019, 'Higher education, technology, and equity in Africa', New Review of Information Networking 24(1), 1-16. https://doi.org/10.1080/13614576.2019.16 08576

Luz, A., 2008, 'The [design of] educational space: A process-centred built pedagogy', in A. Clarke, M. Evatt, P. Hogarth, J. Lloveras \& L. Pons (eds.), International Conference on Engineering and Product Design Education proceedings, Universitat Politecnica de Catalunya, Barcelona, Spain, 4-5 September 2008, pp. 339-344.

Madikizela-Madiya, N., 2016, Space and academic identity construction in a higher education context: A self-ethnographic study, Unpublished thesis, University of South Africa, Pretoria.

Martinez-Vargas, C., Walker, M. \& Mkwananzi, F., 2020, 'Access to higher education in South Africa: Expanding capabilities in and through an undergraduate photovoice project', Educational Action Research 28(3), 427-442. https://doi.org/10.1080/09 650792.2019.1612767

Mathebula, M., 2019, 'Recognising poor black youth from rural communities in South Africa as epistemic contributors', Cristal Critical Studies in Teaching and Learning 7(1), 64-85. https://doi.org/10.14426/cristal.v7i1.181

McCowan, T., 2012, 'Is there a universal right to higher education?' British Journal of Educational Studies 60(2), 111-128. https://doi.org/10.1080/00071005.2011.648605

Mendaglio, S., 2013, 'Gifted students' transition to university', Gifted Education International 29(1), 3-12. https://doi.org/10.1177/0261429412440646

Middleton, A., 2018, Reimagining spaces for learning in higher education, Palgrave Macmillan, Basingstoke.

Moroni, S., 2020, 'The just city. Three background issues: Institutional justice and spatial justice, social justice and distributive justice, concept of justice and conceptions of justice', Planning Theory 19(3), 251-267. https://doi.org/10.1177/ 1473095219877670

Morris, N., 2015, 'Providing ethical guidance for collaborative research in developing countries', Research Ethics 11(4), 211-235. https://doi.org/10.1177/ 1747016115586759

Mukwambo, P., 2016, Quality as human development: A case study of teaching and learning in Zimbabwean universities, Unpublished thesis, University of the Free State, Bloemfontein.

Ndofirepi, E.S., 2020, 'Campus social space in higher education', in A.P. Ndofirepi \& M. Musengi, Inclusion as social justice: Theory and practice in African higher education, pp. 392-408, Brill, Boston, MA.

Nel, C., Troskie-de Bruin, C. \& Bitzer, E., 2009, 'Student transition from school to university: Possibility for a pre-university intervention', South African Journal of Higher Education 23(5), 974-991. https://doi.org/10.4314/sajhe.v23i5.48811

Nussbaum, N., 1997, 'Capabilities and human rights', Fordham Law Review 66, 273-300.

Nussbaum, M.C., 2007, Capabilities as fundamental entitlements: Sen and social justice, Routledge, London.

Nussbaum, M.C., 2011, Creating capabilities: The human development approach, Belknap Press, Cambridge.

Johnson, P.A., Bookman, A., Bailyn, L., Harrington, M. \& Orton, P., 2011, 'Innovation in ambulatory care: A collaborative approach to redesigning the healthcare workplace', Academic Medicine 25, S581-S585.

Pirie, G.H., 1983, 'On spatial justice', Environment and Planning A 15(4), 465-473. https://doi.org/10.1068/a150465

Proctor, J. \& Anand, P., 2017, 'Is credit associated with a high quality of life? A capabilities approach', Progress in Development Studies 17(4), 1-25. https://doi. org/10.1177/1464993417716359 
Robeyns, I., 2003, 'Sen's capability approach and gender inequality: Selecting relevant capabilities', Feminist Economics 9(2/3), 61-92. https://doi. relevant capabilities, Feminist Econ

Ruger, J.P., 2004, 'Health and social justice', Lancet 364(9439), 1075-1080. https:// doi.org/10.1016/S0140-6736(04)17064-5

Ruszynyak, L., Dison, L., Moosa, M. \& Poo, M., 2017, 'Supporting the academic success of first-year students: A study of the epistemological access they acquired through a lecture and text', South African Journal of Higher Education 31(1), 217-226. https://doi.org/10.20853/31-1-1026

Sen, A., 2000, Social exclusion: Concept, application, and scrutiny, social development Paper no.1, Office of Environment and Social Development, Asian Development Bank, Manila.

Sen, A., 2004, 'Capabilities, lists, and public reason: Continuing the conversation', FeministEconomics 10(3), 77-80. https://doi.org/10.1080/1354570042000315163

Sen, A., 2005, 'Human rights and capabilities', Journal of Human Development and Capabilities 6(2), 151-166. https://doi.org/10.1080/14649880500120491

Sharma, G., 2017, 'Pros and cons of different sampling techniques', International Journal of Applied Research 3, 749-752.

Soja, E.W., 1980, 'The socio-spatial dialectic', Annals of the Association of American Geographers 70(2), 207-225. https://doi.org/10.1111/j.1467-8306.1980.tb01308.x

Soja, E.W., 1989, Postmodern geographies: The reassertion of space in critical social theory, Verso, London.

Sulkowski, M.L. \& Lazarus, P.J., 2017, Creating safe schools and fostering students mental health, Routledge, New York, NY.

Surmiak, A., 2018, 'Confidentiality in qualitative research involving vulnerable participants: Researchers' perspectives', Forum Qualitative Sozialforschung/ Forum: Qualitative Social Research 19(3). https://doi.org/10.17169/fqs-19.3.3099

Surmiak, A., 2019, 'Should we maintain or break confidentiality? The choices made by social researchers in the context of law violation and harm', Journal of Academic Ethics 18, 229-247. https://doi.org/10.1007/s10805-019-09336-2

Temple, P., 2009, 'From space to place: University performance and its built environment', Higher Education Policy 22(2), 209-223. https://doi.org/10.1057/hep.2008.30

Tumuheki, P.B., Zeelen, J. \& Openjuru, G.L., 2016, 'Towards a conceptual framework for developing capabilities of "new" types of students participating in highe education in sub-Saharan Africa', International Journal of Educational Development 47, 54-62. https://doi.org/10.1016/j.ijedudev.2015.12.005
Vaismoradi, M., Jones, J., Turunen, H. \& Snelgrove, S., 2016, 'Theme development in qualitative content analysis and thematic analysis', Journal of Nursing Education and Practice 6(5), 100-110. https://doi.org/10.5430/jnep. Education

Van Wyk, J., 2015, 'Can SPLUMA play a role in transforming spatial injustice to spatial justice in housing in South Africa?', Southern African Public Law 30(1), 26-41. https://doi.org/10.25159/2522-6800/3526

Walker, M., 2019, 'The achievement of university access: Conversion factors, capabilities and choices', Social Inclusion 7(1). https://doi.org/10.17645/si. v7i1.1615

Walker, M. \& Mkwananzi, F, 2015, 'Challenges in accessing higher education: A case study of marginalised young people in one South African informal settlement', International Journal of Educational Development 40, 40-49.

Walker, M. \& Wilson-Strydom, M., 2017, 'Thinking about the university context and socially just pedagogies, in M. Walker \& M. Wilson-Strydom (eds.), Socially just pedagogies, capabilities and quality in higher education: Global perspectives, pp. 3-20, Palgrave Macmillan, London.

Wilson-Strydom, M., 2011, 'University access for social justice: A capabilities perspective', South African Journal of Education 31(3), 407-418. https://doi. org/10.15700/saje.v31n3a544

Wilson-Strydom, M., 2014, 'Taking up the challenge of implementing higher education for the public good', South African Journal of Science 10(110), 3-4. https://doi. org/10.1590/sajs.2014/a0055

Wilson-Strydom, M., 2015, 'University access and theories of social justice: Contributions of the capabilities approach', Higher Education 69(1), 143-155. https://doi.org/10.1007/s10734-014-9766-5

Wilson-Strydom, M., 2016, 'A capabilities list for equitable transitions to university: A top-down and bottom-up approach', Journal of Human Development and Capabilities 17(2), 145-160. https://doi.org/10.1080/19452 829.2014.991280

Zeivots, S. \& Schuck, S., 2018, 'Needs and expectations of a new learning space: Research students' perspectives', Australasian Journal of Educational Technology 34(6), 27-40. https://doi.org/10.14742/ajet.4516

Zheng, Y. \& Walsham, G., 2008, 'Inequality of what? Social exclusion in the e-society as capability deprivation', Information Technology and People 21(3), 222-243. https://doi.org/10.1108/09593840810896000 